Submitted: 18.10.2021 - Accepted: 20.12.2021

Year: December 2021 - Volume: 2 - Issue: 2

DOI: $10.47333 /$ modernizm.2021273782

\section{"TRUTH IS AN ODD NUMBER": MODERNISM AND THE EARLY POSTMODERNISM OF FLANN O'BRIEN'S AT SWIM-TWO-BIRDS}

\section{"GERÇEK BIR TEK SAYIDIR": FLANN O'BRIEN'IN AT SWIM-TWO-BIRDS ROMANINDA MODERNIZM VE ERKEN POSTMODERNIZM}

İncihan HOTAMAN ${ }^{1}$

\begin{abstract}
This paper explores Flann O'Brien's novel, At SwimTwo-Birds (1939) in a unique position located right between modernism and postmodernism. Influenced by Irish Modernism as well as Irish Nationalism, the novel carries some significant elements from Irish mythology into the present day and creates a superimposition of the historical and the modern. Moreover, its postmodern take on creative processes and the autonomy of characters within itself reveals the novel's highly metafictional and self-reflexive in nature, which at first seems to be in conflict with its modernist roots. In addition, the distinctive postmodernist essence of $A t$ Swim-Two-Birds can be considered to be the precursor to John Fowles' Mantissa. Moreover, the clash of modernist and postmodernist elements in the novel emphasizes the difference between the two movements as O'Brien uses postmodernist techniques to challenge the modernist ones he, himself, uses frequently. In this regard, he demystifies concepts such as myth, literary creation and being a young artist through its humorous yet critical take on the unnamed narrator.
\end{abstract}

Keywords: Modernism, Early Postmodernism, Metafiction, Frame Narrative, Irish Nationalism, Irish Modernism

\begin{abstract}
Öz
Bu makale, Flann O'Brien'ın At Swim-Two-Birds (1939) adlı romanını modernizm ve postmodernizm arasında yer alan benzersiz bir konumda incelemektedir. İrlanda Modernizminden ve İrlanda Milliyetçiliğinden etkilenen roman, İrlanda mitolojisinden bazı önemli unsurları günümüze taşır ve tarihsel ile modernin bir sürempresyonunu yaratır. Üstelik yaratıcı süreçleri ve karakterlerin kendi içindeki özerkliğini postmodern bir bakış açısıyla ortaya koyan roman, ilk bakışta modernist kökleriyle çelişiyormuş gibi görünen üstkurmacalı ve özdüşünümsel doğasını da gözler önüne serer. Buna ek olarak, At Swim-Two-Birds'ün karakteristik postmodernist özü, John Fowles'ın postmodern romanı Mantissa'nın da bir öncüsü olarak kabul edilebilir. Bununla birlikte, O'Brien, kendisinin de sıklıkla kullandığı modernist tekniklere meydan okumak için metinde görülen postmodernist teknikleri kullanır; bu modernist ve postmodernist unsurların belirgin çatışması iki edebi akım arasındaki farkı bir kez daha ortaya koyar. Yazar bu süreç içerisinde mit, edebi yaratım ve genç sanatçı olma gibi kavramları, isimsiz anlatıcıya mizahi ama eleştirel yaklaşımıyla aydınlatır.
\end{abstract}

Anahtar Kelimeler: Modernizm, Erken Postmodernizm, Üstkurmaca, Çerçeve Hikaye, İrlanda Milliyetçiliği, İrlanda Modernizmi

Ninian Mellamphy once said that Flann O'Brien's At Swim-Two-Birds has the "distinction of being an acclaimed masterpiece that is as often praised as read and more often read than understood" (8). The reason behind its difficult-to-understand nature is

\footnotetext{
${ }^{1}$ Res. Assist., Cappadocia University, The Department of English Language and Literature, incihan.hotaman@kapadokya.edu.tr, ORCID: 0000-0001-6105-7869
} 
perhaps the curious balance it has between modern and postmodern elements. In this regard, on one hand, there are critics like P. L. Henry, who defends that the novel is definitely "in the mainstream of modernist introverted fiction" (38) and Gregory Dobbins, who refers to it as "a quintessential modernist novel" (87); on the other hand, others like Robert Alter claim that At Swim-Two-Birds is "one of the earliest postmodern novels" (qtd in McMullen 63). With elements derived from Celtic twilight and Irish Literary revival, as well as some highly postmodern concepts such as metafiction and parody, the novel does not seem to fit into one single category easily. Therefore, in order to explore the issue and speculate on the questions surrounding the aforementioned novel, this paper will examine and discuss the modern and postmodern elements in At Swim-Two-Birds, including the way it relates to Irish Modernism and Postmodernism, along with its many similarities with John Fowles' postmodern work, Mantissa.

Born in 1911, Brian O'Nolan, who used numerous pseudonyms such as Myles na Gopaleen and Flann O'Brien, wrote his first novel At Swim-Two-Birds in 1939 (Henry 35; Dobbins 93). While his novel was reviewed positively in some literary circles, there remained a general disinterest from the public as a result of political tensions caused by the upcoming war. In fact, O'Brien jokingly comments that the reason behind his novel's lack of sales was the fact that "Adolf Hitler hated At Swim-Two-Birds so vehemently he started World War II in order to interfere with its sales" (Gass v). The novel takes the reader through the life and writing process of a young unnamed narrator who is highly opinionated, intelligent and extremely lethargic - just like his anti-hero Trellis who is "the laziest character in all of Irish literature" (Dobbins 87). The nameless narrator shares with us not only various biographical anecdotes covering a nine-month period, but also the novel he writes. He is writing about another novelist named Dermot Trellis who both creates and borrows various characters for his own novel, and then forces them to live with him, thus creating the main plot of the whole novel: the characters' rebellion against Trellis, their allpowerful creator. The reason behind their rebellion is Trellis' tendency to force his characters into situations they don't want to be in; for example, he forces Furriskey to become an immoral and shameless man, while, in reality, all Furriskey wants to achieve is to marry the girl he loves. However, as Dermot Trellis is an extremely inactive man who values his sleep more than anything, his characters start to drug him periodically to make sure they are not forced to live through the nightmares he has in store for them. But things take a strange turn when Trellis becomes overcome with lust after creating the character 
of the Sheila Lamont and assaults her. The child born out of this situation -Orlick Trellisinherits the talent of literary creation from his father whom he has a deeply rooted hatred for. After some encouragement from Trellis' other characters, Orlick starts writing about his father, Dermot Trellis in order to control his fate like he has been controlling the others'. Yet, Orlick's intricate plan regarding his father's torture and trial does not bear fruit, as at the very last moment, Dermot Trellis' maid burns his manuscript, destroying all the characters he has created and thus, saving him.

Full of allusions to Irish mythology, parodies and layers upon layers of narration, the novel has such a complex structure that Monique Gallagher claims that it is "not one book, but four books" (128) since at certain points it is possible to count at least four layers of frame-narration, including the narrations of O'Brien, Unnamed Student, Trellis and Orlick. Thus, through such levels of intricacy, it is incredibly difficult to differentiate whether the novel is a work of modernism or postmodernism. When we look at modernism for answers regarding this troublesome question, we come to realize that Irish modernism of 1930s has certain distinctive qualities, such as its connection to the colonial history of Ireland which Francis Mulhern defines as "by virtue of its sheer duration is more like a history of colonization itself" (qtd in Dobbins 86). In regard to this, Gregory Dobbins suggests that the connection between Irish Nationalism and Irish Modernism is surprisingly strong, as he explains that aside from focusing on the traditional past in the pre-independence era, Irish Nationalism after the independence of the Irish Free State "became one of the primary agents of modernization in Ireland" (87) and thus, it is possible to find various similarities between modernist Irish works and works derived from national or local sources. Dobbins goes on to refer to Irish modernism as "a consequence of the political, social, economic, and cultural backwardness of Ireland than of the progressive elements of modernity" (91) which is one of the main elements that deem Irish modernism distinctive and different from the international understanding of it. In addition to this, Terence Brown agrees with Dobbins' assertion and clarifies that Irish Literary Revival that came along with Irish Nationalism brought traces of European Romanticism and its obsession with the past, hero worship, and veneration of the rural and primitive, all of which, combined with the progressiveness of modernism, resulted in the fact that "[h]istorical time and mythological timelessness are woven together in a seamless garment of national imagining" (95). He further explains that through the connection between Irish Literary Revival and modernism, "[c]ontext and text formed a culture in which the kinds of technical devices and the sense of reality Modernism and its accompanying critique would internationalise were 
contemporaneously aspects of the Revival project and probably influenced, consciously and unconsciously, the Irish contribution to the general movement"; therefore, it is understandable that the Revival and Irish Modernism exhibit "parallels of outlook and method" (Brown 98). An example to this may be given from Yeats and Joyce both of whom incorporated classical or mythological elements to their modernist works; while Yeats used the character Cuchulainn, a mythical hero from Irish folklore, both in his poetry and plays, Joyce borrowed Homeric models, and thus, transposed older literary characteristics into modern contexts (Dobbins 98). However, Brown points out that in the post-independence era, merging of the modern with the nationalist historical became a rare sight to behold as he further explains that

So disillusioned, post-revolutionary literary Ireland seems to have thrown out the Modernist baby with the Romantic bathwater of the Literary Revival, leaving the 1930s to produce only a few writers, like genetic sports, who wrote in varying degrees of awareness of the Revival's formal originality or of Modernism's revolution of the word. At the very least, until Flann O'Brien in 1939 published At Swim-Two-Birds, there did not occur that curious coincidence of literary taxonomies in which a work rooted in aspects of Revival poetics (I am thinking of the parodic Revival epic descriptions and the version of Buile Suibhne which it contains) is also an entry in the Modernist (and even the post-modern) canon. (99)

Indeed, At Swim-Two-Birds, Dermot Trellis's novel in particular, is the prime example of this phenomenon of merging the modern with the historical, with its mythical and epic characters such as Sweeney and Finn Mac Cool (better known as Fionn mac Cumhaill of Irish folklore). Through these characters and their stories, which more often than not, are told in a language mimicking an archaic one, At Swim-Two-Birds succeeds in weaving the modern time of the unnamed narrator with mythical time of Finn and Sweeney. Through his biographical anecdotes in the novel, the unnamed narrator relays the temperament of his time, and through the stories of Sweeney and Finn Mac Cool, he merges his modern narration with that of a medieval one, and thus, creates a composition of mixed time and language throughout the novel. Especially the language he uses in the epic and mythical parts of the narration is rather distinctive, as it can be observed in the physical description of Finn Mac Cool,

Too great was he for standing. The neck to him was as the bole of a great 
oak, knotted and seized together with muscle-humps and carbuncles of tangled sinew, the better for good feasting and contending with the bards. $[\cdots]$ The arms to him were like the necks of beasts, ball-swollen with their bunched-up brawnstrings and blood-veins, the better for harping and hunting and contending with the bards. Each thigh to him was to the thickness of a horse's belly, narrowing to a green-veined calf to the thickness of a foal. Three fifties of fosterlings could engage with handball against the wideness of his backside, which was wide enough to halt the march of warriors through a mountain-pass. (O'Brien 17-18)

Aside from emphasizing the difference of the linguistic style used by the narrator for conveying daily matters, this use of the language has critical importance in the novel, as it conveys intention on O'Brien's side. As a scholar of Irish literature who focused on Old and Middle Irish in his master's thesis on "Nature in Irish Poetry" at University College (McMullen 76), O'Brien's use of epic language in the form of Anglo-Irish suggests that he not only uses the language purposefully, but he also intends to "present in his novel a more or less accessible version of certain Gaelic tradition $[\cdots]$ [since] the traditions of great Gaelic notables with their sagas were familiar to him" (Henry 36). By combining the language of myths and epics with the modern language of the young student, O'Brien once again merges "medieval Gaelic story-telling with modern fiction in English" (Henry 36) which not only is a sign of Irish Modernism, but also proves the point made by Terence Brown regarding the modernist nature of the novel and how it relates to the superimposition of historical and modern elements.

On one hand, critics like Brown and Dobbins suggest that the combination of elements from epic and modern times indicates modernism in the novel, while on the other hand others like Kim McMullen questions their reasoning for doing so. She argues that the traces of Irish Revival we see in the form of mythical and epic stories and characters in the novel are not there to suggest modernist objectives, but to challenge the Irish "cultural inheritance through energetic dialogism" (76) which would suggest that the purpose of the presence of epic and cultural elements in the novel is, in fact, a postmodern one. McMullen defends that "Flann O'Brien who was born into that first, critical and cosmopolitan, postindependence generation was also paradoxically more familiar with Irish traditions than many of the Revivalists who embraced them or the Modernists who rejected them", and thus, instead of purposefully creating a mixture of modern and epic that would be a fine example of Irish Modernism with a touch of Irish Literary Revival, the novel is actually "both 
problematizes and celebrates its cultural inheritance through a parodic strategy that is distinctly postmodern" (76). Moreover, Joshua Esty agrees with McMullen and explains that right from the beginning of the novel, "O'Brien unleashes a firestorm of parodie languages and comic pastiche built on a story-within-a-story-within-a-story structure that is both intricate and unruly [and] [g]iven its metafictional musings and relentless intertextuality, the novel could almost be taken as a manifesto for postmodern fiction" (24).

Likewise, the self-reflexive, postmodern techniques used in the novel also make themselves rather clear in the novel's aspiration to be a "self-evident sham" (Esty 36; O'Brien 33). In this regard, Monique Gallagher indicates that aside from the selfconsciousness of the novel, its self-reflexiveness is another significant aspect of it, since "the text includes several narrative voices it also reflects novelistic modes, and, because it is concerned with its own art, it is a work that reflects upon itself, in intertextual references and echoes" (128). For example, at the end of the novel, having survived the attempt on his life with the skin of his teeth, Trellis comments that "I have done too much thinking and writing, too much work" (O'Brien 313), and thus acknowledges "the failure of fiction that exposes its own fictionality" (Dobbins 94). In addition, with the inclusion of multiple narrative voices - the Student's, Trellis', Orlick's and more - At Swim-Two-Birds also reflects multiple novelistic modes dependent on their respective narrators which indicate that it is, indeed, "concerned with its own art, it is a work that reflects upon itself" (Taaffe 128). Moreover, the fact that right at the opening of the novel, our nameless narrator asserts that "[o]ne beginning and one ending for a book was a thing I did not agree with. A good book may have three openings entirely dissimilar and inter-related only in the prescience of the author, or for that matter one hundred times as many endings" (O'Brien 9) also suggests reflexivity on the novel's very nature. Furthermore, it is also very telling that while the nameless narrator takes pages upon pages to relay trivial matters regarding his daily life or the irrelevant stories of Trellis' characters, the real advancement of the plot always happens in the form of short synopses taking up only a couple pages.

This indicates that neither the advancement of the plot nor the development of the chain of events are the primary concern of the narrator, whereas the feedback he receives from his friends and readers is; this is why in multiple parts of the novel, we find the narrator talking with others about the novel he is writing and we are reading. Therefore, it is clear that the multiple narratives of the novel comment both on one another and on themselves, which suggests that the novel reflects on itself and adds to its own 
postmodern qualities. In fact, at certain points, this self-reflexivity of the novel leads to metafictional qualities, as characters themselves do not shy away from commenting the way the narration is shaped; for example, while Orlick is narrating the torture of his father Trellis, he is frequently interrupted by the others around him, such as Shanahan who voices his displeasure with Orlick's decorated language and elaborative plot with the lines "I beg your pardon, Sir, said Shanahan, but this is a bit too high up for us. This delay, I mean to say. The fancy stuff, couldn't you leave it out or make it short, Sir? Couldn't you give him a dose of something, give him a varicose vein in the bloody heart and get him out of that bed?" (O’Brien 239). Moreover, by sharing his discontent, Shanahan not only makes a note on the elevated language Orlick uses, but also acknowledges the fictional nature of the narration he is both in the process of making and currently is in. Interruptions like this, which comments on the fictionality of the text itself, pushes the metafictional qualities of the novel to the foreground and demonstrates the fact that At Swim-Two-Birds is very much aware of its own fictionality. Both this self-reflexiveness and metafiction are points indicating that the novel is, indeed, a postmodern one, because, as Linda Hutcheon explains, "postmodern fiction manifests a certain introversion, a self-conscious turning toward the form of the act of writing itself" (128).

Another postmodern feature of the novel is its obvious parodical nature; in fact, Carol Taaffe argues that the mode that "dominates the novel is parody and [O'Brien] cunningly exploits all the ambiguity which this offers" (252). O'Brien not only parodies the myths of Celtic twilight by challenging it and its language as we have mentioned before, but also questions the inherited cultural narratives while "recontextualize[ing] these narratives by bringing them into dialogue with critical needs and conditions of the present" (Esty 27; McMullen 77). Moreover, a parodical text like At Swim-Two-Birds "uses its historical memory, its aesthetic introversion, to signal that this kind of self-reflexive discourse is always inextricably bound to social discourse" (Hutcheon 35) which is exactly what we witness in the novel, through the parodies of not only the cultural texts but also the everpopular artist-as-a-young-man trope. Through characters such as bloodthirsty but elaborative Orlick, the lazy student and even lazier Trellis, who have the power to influence their respective narrations as they please, O'Brien is both rewriting what it means to be an artist and challenging the concept of the young artist, popularized and romanticized by James Joyce's Stephen Dedalus. Taaffe, agreeing with this point, clarifies that O'Brien's unnamed narrator "undermine[s] the romantic image of [the artist]" (256), while Gallagher goes as far as to claim that "At Swim-Two-Birds is a second-degree "Portrait of the Artist 
as a Young Man"' (129). Indeed, the young narrator who aspires to be the writer of a new type of fiction is very evocative of young Stephen Dedalus; however, the fact that our lethargic unnamed narrator is nothing like the somber Stephen brings us back to the fact that the sole reason for the similarities between the two is to parody the way Joyce and others romanticizes the idea of a young artist; or, as Linda Hutcheon puts it "[i]n using parody in this way, postmodernist forms [like At Swim-Two-Birds] want to work toward a public discourse that would overtly eschew modernist aestheticism and hermeticism and its attendant political self-marginalization" (23). In addition, McMullen implies that the differences between the young artists end here in order to deconstruct the concept of the romanticized artist by highlighting their differences as she further explains that in a way, O'Brien

rewrites Portrait to subvert any Modernist desire to transcend nets of nation, language, and Church in order to discover an eternal value in art. It de-mythologizes the exile of the heroic artist by demonstrating the degree to which the cultural horizons of its own artist protagonists are already written, and it articulates a postmodern aesthetic that stands in selfconscious defiance of Stephen's own program. [‥] While Joyce might ironize Stephen's pretensions to the aesthetic priesthood, O'Brien's student artist mocks his own pretensions $[\cdots]$ the student's self-ironizing aesthetic -obviously a reflexive reference to At Swim-Two-Birds itself- subverts the Modernist desire to escape the nightmare of history in a transcendent unitary vision (McMullen 77)

Aside from these points advocating the postmodern nature of the novel, there is one more detail that adds to it: At Swim-Two-Birds' irrefutable resemblance to John Fowles' postmodern novel, Mantissa (1982), which tells the story of the struggle between Miles Green, an author, and his muse, Erato. The reason behind the similarities between the two novels is perhaps, O'Brien's strong influence on Fowles, as he himself admits by saying that "[i]f I went in for dedicating books to other writers, I would have dedicated [Mantissa] to Flann O'Brien" (Fowles qtd in White 155). In fact, Fowles not only praises O'Brien's talent, but also refers to him as "one of the finest Irish writers of this century and a major figure in the development of the self-conscious novel since the death of Joyce" while admitting that "[t] he ghost behind Mantissa is very much Flann O'Brien's At Swim-TwoBirds" (Barnum and Fowles 201). 
In Mantissa, the conflict between Miles Green, the author and his muse Erato is based on the concept of creative authority one has over text, which is very similar to what we witness in O'Brien's novel, between Trellis and his characters. As lan Gotts defends "Miles becomes as helpless before the contents of his narrative as Trellis before his" (88); while Miles Green does not recognize Erato as a significant part of his writing process and denies her any authority over text, the characters of Dermot Trellis struggle to have authority over the text that shapes their lives. Therefore, in order to have a semblance of authority and autonomy, they resort to drugging their creator. By making sure that they have absolute control over the text, Trellis' characters manage to get the lives they wanted from the beginning as it can be understood from this excerpt:

TRELLIS, almost perpetually in a coma as a result of the drugs secretly administered by Mr Shanahan, makes little progress with the design of his story, with the result that JOHN FURRISKEY is enabled to enjoy almost uninterrupted marital bliss with his wife (Mrs Furriskey), while MESSRS LAMONT \& SHANAHAN continue to live a dissolute if colourful life. (O’Brien 214-215)

Furthermore, just as the characters are achieving their dream of being free of Trellis, the creative authority belonging not to Trellis, but to the unnamed student narrator makes itself known and shapes the outcome of the tale by making Trellis' maid burn the manuscript and destroy the very characters who struggle for autonomy and authority. Thus, the unnamed narrator assumes "the role of the omnipotent godlike creator" (Gallagher 131), saves Trellis from his own failure and proves that "[w] riting is complicit with power in At Swim-Two-Birds" (Dobbins 104). In terms of this creative authority, Mellamphy emphasizes that "Trellis is no God; he is at best Frankenstein - and a debased Frankenstein at that" (21), because while he performs the act of creation through what is defined as aestho-autogamy - the act of "producing a living mammal from an operation involving neither fertilization nor conception" (O'Brien 55) - and tries to assume a divine role by communicating with Furriskey through a godlike voice (O'Brien 68), he fails to keep Furriskey and his other characters under control, as they start to rebel against him and his intentions. For example, Trellis creates Furriskey with the purpose of creating an immoral and depraved man, so that he, as the author, would be able to tell a moral and didactic tale about modern vices (O'Brien 85-86). However, Furriskey's own personal aspirations are on the opposite side of the spectrum; therefore, in order to be free of the path Trellis devised for him, he chooses to drug his creator and live a happily married life with his beloved, 
while Trellis remains asleep (O’Brien 141).

Another important point of likeness between the two novels is the way they include sexual acts within the process of birth and creation of a text; in Mantissa the text is created through a sexual relationship with the muse and the consequent childbirth suffered by the author (Fowles 22), whereas in At Swim-Two-Birds this creation process is depicted in two ways. The first being the process of aestho-autogamy which is depicted in the novel as a process where children/characters are born/created as fully grown adults, without needing the actual processes of conception and birth. In fact, the creation/birth of Furriskey who is born "at the age of twenty-five and entered the world with a memory but without a personal experience to account for it" is a great example to this (O'Brien 10). Moreover, the second act of creation in the text, just like Mantissa, is related to sexual acts, as we come to realize that in a Pygmalion fashion, "Trellis creates Miss Lamont in his own bedroom and he is so blinded by her beauty (which is naturally the type of beauty nearest to his heart), that he so far forgets himself as to assault her himself" (O'Brien 86). As a result of this situation, Orlick Trellis, who would eventually sit down to write about Dermot Trellis' terrible end through the same creative power he inherited from Dermot, is born. While the similarities between Fowles' postmodern Mantissa and O'Brien's At Swim-Two-Birds do not simply end here, in light of the facts listed here, we can conclude that resemblance between the two novels is too uncanny to be a coincidence, especially coupled with Fowles' open admiration of O'Brien. Hence, it would be fair to say that while modernism and postmodernism of At Swim-Two-Birds is still open to discussion, the fact remains that O'Brien's novel is a successful precursor of the metafictional, self-reflexive postmodern novels.

In conclusion, while it is still very hard to categorize At Swim-Two-Birds, the definitions we have for postmodern techniques list some of the key elements found in the novel, such as parody, metafiction and self-reflexivity. Moreover, Blignaut indicates that "postmodern literature [has] the tendency [‥] to demystify and defamiliarise myth" which can be observed in two ways in the text: firstly, through its parodies on the concept of the young artist, the novel actually "dethrones the Modern artist, returning his or her voice to the general cultural colloquy" (McMullen 78) and destroys the grand narrative of the romanticized, idealistic author; secondarily, through its - mostly humoruous - use of the Anglo-Irish language and characters from Irish mythology within the context of parody, the novel both enthrones the cultural texts it inherits and demystifies them at the same time. 
However, this is not to say that the novel is only or purely postmodern; not only its year of publishing is too early for that type of categorization (1939), but also as Linda Hutcheon points out, "postmodernism does not entirely negate modernism" (30) since it has a "contradictory dependence upon and independence from the modernism that both historically preceded it and literally made it possible" (23). Therefore, the presence of modern and postmodern elements within Flann O'Brien's At Swim-Two-Birds suggests both a break with the modernist concepts and ideals, and a tentatively new type of approach to writing. In regard to this, Terence Brown asserts that the distinctiveness of Irish Modernism that helped modernist writers such as Joyce and Yeats, would undoubtedly be followed by authors "defined by Modernist characteristics while anticipating post-modern effects" (88) which is the most apt description of O'Brien and his novel one can possibly give.

\section{WORKS CITED}

Blignaut, Truida-Marthe. "Creating a Postmodern Myth: the Use and Function of Classical Allusion and Myth in Selected Novels of John Fowles." PU vir CHO, 1994.

Brown, Terence. "Ireland, Modernism and the 1930s." The Literature of Ireland: Culture and Criticism. Cambridge University Press, Cambridge, 2010, pp. 88-103.

Barnum, Carol M. and John Fowles. "An Interview with John Fowles." Modern Fiction Studies, vol. 31, no. 1, 1985, pp. 187-203. JSTOR, www.jstor.org/stable/26281415. Accessed 8 Feb. 2021.

Dobbins, Gregory. "Constitutional Laziness and the Novel: Idleness, Irish Modernism, and Flann O'Brien's 'At Swim-Two-Birds." NOVEL: A Forum on Fiction, vol. 42, no. 1, 2009, pp. 86-108. JSTOR, www.jstor.org/stable/40267755. Accessed 3 Feb. 2021.

Esty, Joshua D. "Flann O'Brien's At Swim-Two-Birds and the Post-Post Debate." Ariel, vol. 26, no. 4, Oct. 1995 , pp. 23-46.

Fowles, John. Mantissa. Little, Brown and Company, 2013.

Gallagher, Monique. "Reflecting Mirrors in Flann O'Brien's 'At Swim-Two-Birds." The Journal of Narrative Technique, vol. 22, no. 2, 1992, pp. 128-135. JSTOR, www.jstor.org/stable/30225357. Accessed 1 Feb. 2021.

Gass, William H. Introduction. "Also Known As An Introduction to At Swim-Two-Birds." At Swim-Two-Birds by O'Brien, Flann. Dalkey Archive Press, 1998, pp. v-xviii. 
Gotts, Ian. "Fowles' Mantissa: Funfair in Another Village." Critique: Studies in Contemporary Fiction, vol. 26, no. 2, 1985, pp. 81-95., doi:10.1080/00111619.1985.9934665.

Henry, P. L. "The Structure of Flann O'Brien's 'At Swim-Two-Birds." Irish University Review, vol. 20, no. 1, 1990, pp. 35-40. JSTOR, www.jstor.org/stable/25484337. Accessed 26 Jan. 2021.

Hutcheon, Linda. A Poetics of Postmodernism: History, Theory, Fiction. Routledge, 2003.

McMullen, Kim. "Culture as Colloquy: Flann O'Brien's Postmodern Dialogue with Irish Tradition." NOVEL: A Forum on Fiction, vol. 27, no. 1, 1993, pp. 62-84. JSTOR, www.jstor.org/stable/1345981. Accessed 8 Feb. 2021.

Mellamphy, Ninian. "Aestho-Autogamy and the Anarchy of Imagination: Flann OBriens Theory of Fiction in at Swim-Two-Birds." The Canadian Journal of Irish Studies, vol. 4, no. 1, 1978, p. 8., doi:10.2307/25512419.

O'Brien, Flann. At Swim-Two-Birds. Dalkey Archive Press, 1998.

Taaffe, Carol. "'Tell Me This, Do You Ever Open a Book at All?': Portraits of the Reader in Brain O'Nolan's 'At Swim-Two-Birds.'” Irish University Review, vol. 34, no. 2, 2004, pp. 247-260. JSTOR, www.jstor.org/stable/25504977. Accessed 6 Feb. 2021.

White, Michael. "Observations on Flann OBriens At Swim-Two-Birds in Translation." Revista Alicantina De Estudios Ingleses, no. 5, 1992, pp. 155-161., doi:10.14198/raei.1992.5.13. 